\title{
HUBUNGAN ANTARA GAYA KEPEMIMPINAN DAN KEPRIBADIAN DENGAN ETOS KERJA PEGAWAI DI KANTORKECAMATAN BONGOMEME KABUPATEN GORONTALO
}

\author{
Siwin C. Ishak, Wenny Hulukati \\ Pascasarjana Universitas Negeri Gorontalo \\ siwin.mahasiswa@ung.ac.id
}

Received: 2 Desember 2019; Revised: 9 Desember 2019; Accepted: 24 Desember 2019

\begin{abstract}
ABSTRAK
Penelitian ini bertujuan untuk: 1) mengetahui hubungan gaya kepemimpinan dengan etos kerja pegawai di Kantor Kecamatan Bongomeme Kabupaten Gorontalo; 2) mengetahui hubungan kepribadian dengan etos kerja pegawai di Kantor Kecamatan Bongomeme Kabupaten Gorontalo; dan 3) mengetahui hubungan antara gaya kepemimpinan dan kepribadian dengan etos kerja di Kantor Kecamatan Bongomeme Kabupaten Gorontalo. Penelitian ini merupakan penelitian korelasi yang menghubungkan tiga variabel yang terdiri dari variabel Gaya Kepemimpinan (X1), variabel Kepribadian $\left(\mathrm{X}_{2}\right)$ dan variabel Etos Kerja Pegawai $(\mathrm{Y})$. Subjek yang digunakan dalam penelitian ini berjumlah 30 orang yang merupakan pegawai yang bekera di lingkungan Kantor Kecamatan Bongomeme Kabupaten Gorontalo. Hasil penelitian menunjukkan bahwa: 1) hasil pengujian pertama mengindikasikan bahwa terdapat hubungan yang signifikan antara gaya kepemimpinan pimpinan $\left(\mathrm{X}_{1}\right)$ dengan etos kerja pegawai $(\mathrm{Y})$, yang ditunjukkan koefisien korelasi sederhana diperoleh koefisien $\mathrm{r}_{\mathrm{y} 1}$ sebesar 0,02 dan koefisien determinasi $\mathrm{r}_{\mathrm{y} 1}^{2}$ sebesar 0,$004 ; 2$ ) hasil pengujian kedua menyimpulkan bahwa terdapat hubungan yang signifikan antara kepribadian pimpinan $\left(\mathrm{X}_{2}\right)$ dengan etos kerja pegawai $(\mathrm{Y})$, yang ditunjukkan koefisien korelasi sederhana diperoleh koefisien $r_{\mathrm{y} 1}$ sebesar 0,99 dan koefisien determinasi $r_{\mathrm{y} 1}^{2}$ sebesar 1; dan 3) hasil pengujian ketiga menyimpulkan bahwa terdapat hubungan yang signifikan antara gaya kepemimpinan $(\mathrm{X} 1)$ dan kepribadian pimpinan $\left(\mathrm{X}_{2}\right)$ dengan etos kerja pegawai $(\mathrm{Y})$, yang ditunjukkan koefisien korelasi multiple regresi. Hal ini mengindikasikan bahwa makin tinggi nilai gaya kepemimpinan dan kepribadian pemimpin yang ditunjukkan dalam kinerjanya, maka akan semakin tinggi etos kerja pegawai.
\end{abstract}

Kata Kunci: Gaya Kepemimpinan, Kepribadian, dan Etos Kerja Pegawai.

\section{PENDAHULUAN}

Kantor Camat Bongomeme, Kabupaten Gorontalo merupakan salah satu instansi pemerintah yang bertugas melayani masyarakat dalam khususnya dalam urusan administrasi dan kepentingan masyarakat. Seperti organisasi pada umumnya etos kerja pegawai akan berpengaruh terhadap layanan yang diberikan oleh pegawai kepada masyarakat. Oleh karena itu, perlunya bagi pegawai untuk meningkatkan etos kerja dalam menyelesaikan pekerjaannya.

Dalam wawancara yang penulis lakukan dengan Kasubag Umum \& Kepegawaian Bapak Gafar Salim Lema, hasilnya menunjukkan bahwa terdapat kecenderungan penurunan disiplin pegawai dalam beberapa bulan terakhir. Selain itu, bapak Gafar juga menambahkan bahwa beberapa pegawai cenderung bersikap apatis 
dan sungkan terhadap pimpinannya sehingga kurang leluasa ketika meminta pelaporan tugas dari yang bersangkutan. Menurunnya tingkat disiplin dan sungkannya pegawai terhadap pimpinan menjadi salah satu gambaran bahwa etos kerja yang berlangsung di Kantor Camat masih kurang. Sementara itu, menurunnya tingkat disiplin pegawai ini dapat ditandai dengan data persentase basensi pegawai di kantor camat Bongomeme tahun 2018:

Berbicara etos kerja sebagai salah satu indikator dalam kinerja pegawai, sangat menarik untuk dihubungkan dengan gaya kepemimpinan dan kepribadian. Sebab tiga aspek ini dapat dijadikan sebagai landasan untuk mencapai tujuan organisasi. Hal ini nantinya akan menjadi masukan demi terciptanya peningkatan dan perbaikan dari sistem yang telah ada.

Berdasarkan uraian di atas, penulis tertarik untuk meneliti hubungan antara gaya kepemimpinan, kepribadian, dan etos kerja di Kantor Kecamatan Bongomeme Kabupaten Gorontalo. Dengan demikian, judul penelitian ini dapat dirumuskan menjadi: "Hubungan antara Gaya Kepemimpinan dan Kepribadian dengan Etos Kerja Pegawai di Kantor Kecamatan Bongomeme Kabupaten Gorontalo".

\section{KAJIAN TEORETIS}

\section{A. Gaya Kepemimpinan}

Gaya Kepemimpinan adalah suatu cara yang digunakan pemimpin dalam berinteraksi dengan bawahannya (Nasution, 2012: 45). Dalam kaitannya, gaya kepemimpinan menekankan pada bagaimana pemimpin menunjukkan sikap terhadap pegawai. Fokus kebanyakan riset dan tulisan tentang kepemimpinan adalah pada sifat dan kepribadian dari orang yang menjadi pemimpin dalam situasi tak terstruktur yang seringkali kacau. Para pemimpin muncul karena mereka dapat membentuk dan mengubah situasi, dan dengan demikian membuat suatu sistem makna bersama yang memberikan dasar untuk tindakan terorganisir.

Soetopo (dalam Puspitasari \& Oktarina, 2018: 317) bahwa "gaya kepemimpinan adalah cara seseorang mempengaruhi serta mengoordinasikan segala kegiatan organisasi untuk mencapai tujuan organisasi". Dalam hal ini, kepemimpinan adalah hubungan dinamis yang menghubungkan antara pimpinan dengan bawahan (pegawai) melalui interaksi dan komunikasi diantara keduanya. Hubungan itu dapat berlangsung secara timbal balik, yang terjadi atas atribut pimpinan. Dalam kaitannya, kepemimpinan merupakan bagian dari manajemen, tetapi tidak secara menyeluruh.

Kepemimpinan merupakan bagian dari manajemen, tetapi tidak semuanya. Kepemimpinan adalah kesanggupan untuk membujuk orang lain untuk mencapai tujuan yang telah ditentukan dengan entusias. Faktor manusialah yang mengikat suatu kelompok dan menggerakannya ke arah sasaran, tindakanlah yang membuat sukses semua potensi yang terdapat dalam organisassi dan orang-orangnya.

Kepemimpinan merupakan kemampuan mempengaruhi dan mengarahkan tingkah laku orang lain, bawahan atau kelompok untuk mencapai tujuan organisasi atau kelompok (Kartono, 2016 dalam Utari, 2018: 1042). Dengan demikian, kepemimpinan merupakan entitas manejerial terhadap organisasi dalam mengarahkan dan mempengaruhi tingkah laku orang lain.

Pegawai negeri sebagai aparatur pemerintah dan sebagai abdi masyarakat diharapkan selalu siap menjalankan tugas dengan baik dan siap melayani masyarakat 
dengan baik. Kinerja pegawai dilihat masyarakat sebagai sorotan yang akan dinilai sebagai hal yang penting bagi masyarakat apakah pegawai tersebut sudah profesional atau layak ditempatkan diinstansi pemerintah atau tidak sebagaimana disebutkan dalam Prayogo (2018: 1149), mengemukakan bahwa kinerja pegawai didefinisikan sebagai kemampuan pegawai dalam melakukan sesuatu keahlian tertentu.

\section{B. Kepribadian}

Masing-masing manusia memiliki kepribadian yang unik, sifat dan karakter yang mempengaruhi cara kita bertindak dan berinteraksi dengan orang lain. Ketika seseorang menceritakan bahwa seseorang itu ramah, terbuka, santai, pemalu, atau agresif, sebenarnya kita sedang menggambarkan kepribadian orang yang bersangkutan.Sebuah organisasi juga memiliki kepribadian, dan biasanya kita menyebutnya dengan "budaya organisasi". Robbins dan Coulter (2010) (dalam Ruffiah, 2018: 1166), mengemukakan budaya organisasi merupakan sehimpunan nilai, prinsip, tradisi, dan cara bekerja yang dianut bersama dan mempengaruhi perilaku serta tindakan para anggota organisasi.

Budaya organisasi adalah kerangka kerja kognitif yang terdiri dari sikapsikap, nilai-nilai, norma perilaku dan harapan bersama yang dirasakan oleh anggota organisasi (Green Berg \& Baron, 2003) dalam Saputri (2018:1132). Oleh karena itu, budaya organisasi merupakan nilai, sikap, asumsi, dan norma perilaku yang hidup dalam suatu organisasi yang membentuk penampilan, sikap, dan tindakan, sehingga menjadi identitas dari organisasi tertentu.

Gordon W. Allport (dalam Yosep, 2003) mendefinisikan kepribadian adalah sebuah tingkah laku yang dimiliki oleh individu secara dimanis yang mampu mengarahkan pada proses perubahan setiap individu. Maksud dinamis pada pengertian tersebut adalah perilaku yang mungkin saja berubah-ubah melalui proses pembelajaran atau melalui pengalaman-pengalaman, reward, punishment, pendidikan, dan sebagainya.

Pengertian diatas menjelaskan bahwa kepribadian merupakan tingkah laku yang dapat dimiliki oleh seseorang yang secara dinamis mengarahkan setiap indivdiu dalam sebuah proses perubahan. George, Zhou (2001) dan Woodman (1993) dalam Williams (2004) menyebutkan bahwa salah satu ciri kepribadian yang dihubungkan dengan kinerjakreatif individu dalam organisasi adalah keterbukaan terhadap pengalaman.

Pengertian di atas merujuk pada ciri-ciri perilaku yang kompleks terdiri dari temperamen (reaksi emosi yang cenderung menetap dalam merespon situasi atau stimulus lingkungan secara spontan), emosi yang bersipat unik dari individu. Reaksi yang berbeda dari masing-masing individu menunjukan perbedaan kepribadian.

Dalam suatu organisasi pasti ada beberapa individu yang mempunyai sikap terbuka dalam segala hal. Individu yang terbuka tersebut cenderung lebih kreatif daripada anggota organisasi yang lain. Karena itu keterbukaan menjadi bagian dari ciriciri kepribadian yang mempunyai kinerja kreatif dalam organisasi. Selain keterbukaan terhadap pengalaman, ciri kepribadian lain yang menjadi bagian dari 5 model utama personalitas adalah ekstraversi, neurotisisme, daya terima, dan sifat kehati-hatian. Dari 5 model utama tersebut, keterbukaan terhadap pengalaman menjadi elemen penting untuk mencapai kreativitas kerja. 
Dari penjelasan di atas dapat disimpulkan bahwa kepribadian adalah ciri-ciri perilaku individu dalam merespon situasi di lingkungannya. Lebih merinci lagi, kepribadian kreatif mengarah pada perilaku yang terbuka terhadap hal-hal baru untuk mendapatkan pengalaman sebanyak-banyaknya. Selain itu, dalam mengidentifikasi individu yang mempunyai kepribadian kreatif dapat diihat dari berbagai perilaku yang kompleks dan berbeda dari orang lain

\section{Etos Kerja}

Etos kerja merupakan konsep yang memandang pengabdian atau dedikasi terhadap pekerjaan sebagai nilai yang sangat berharga (Istijanto, 2005: 35). Secara etimologis, etos berasal dari bahasa Yunani "ethos" yang berarti karakter, watak kesusilaan, kebiasaan atau tujuan moral seseorang serta pandangan dunia mereka, yakni gambaran, cara bertindak ataupun gagasan yang paling komprehensif mengenai tatanan (Novliadi, 2009:4)

Menurut Arief dan Tanjung (2003) etos kerja adalah jiwa atau watak seseorang dalam melaksanakan tugasnya yang di pancarkan keluar, sehingga memancarkan citra positif atau negatif kepada orang luar orang bersangkutan. Pegawai yang mempunyai etos kerja tinggi tercermin dalam perilakunya, seperti suka bekerja keras, bersikap adil, tidak membuang-buang waktu.

Menurut Poniman et al, (dalam penelitian Husen Sutisna, 2008) Etos kerja dibagi menjadi tiga dimensi yaitu kerja keras, kerja cerdas dan kerja ikhlas.Tiga dimensi ini merupakan garis besar dari ciri -ciri orang yang etos kerja tinggi (dalam Nugroho, 2006). Sedangkan etos kerja profesional adalah seperangkat perilaku kerja positif yang berakar pada kesadaran yang kental, keyakinan yang fundamental, disertai komitmen yang total pada paradigma kerja yang integral. Setiap organisasi yang selalu ingin maju akan melibatkan anggota untuk meningkatkan mutu kerjanya, diantaranya setiap organisasi harus memiliki etos kerja (Jansen, 2011:4)

Menurut Sinamo (2011:55) etos kerja adalah totalitas kepribadian diri serta cara mengekspresikan, memandang, meyakini, dan memberikan makna pada sesuatu, yang mendorong diri untuk bertindak dan meraih amal yang optimal. Lebih lanjut, Sinamo (2011:56) membagi etos kerja menjadi tiga dimensi dengan beberapa indikator yang menyertainya, antara lain: 1) kerja cerdas dengan indikator: a) kerja adalah seni, bekerja cerdas penuh kreativitas, b) kerja adalah kehormatan, bekerja tekun penuh keunggulan; 2) kerja keras dengan indikator: a) kerja adalah aktualisasi bekerja keras penuh semangat, b) kerja adalah amanah, bekerja benar penuh tanggungjawab, c) kerja adalah panggilan bekerja tuntas penuh integritas; 3) kerja ikhlas dengan indikator: a) kerja adalah rahmat, bekerja tulus penuh rasa syukur, b) kerja adalah ibadah, bekerja serius penuh kecintaan, c) kerja adalah pelayanan, bekerja paripurna penuh kerendahan hati.

\section{METODE PENELITIAN}

Metode yang digunakan dalam penelitian ini adalah metode deskriptif verifikatif. Metode ini menurut Sugiyono (2008:86) adalah metode yang digunakan dalam mencari fakta di lapangan dengan interpretasi yang tepat. Jenis penelitian ini tergolong sebagai penelitian yang menggambarkan fenomena-fenomena yang ditemukan di lapangan. Bentuk verifikatif yang dimaksud dalam penelitian ini adalah untuk mengetahui hubungan atau keterkaitan antara gaya kepemimpinan dan kepribadian dengan etos kerja pegawai di Kantor Kecamatan Bongomeme Kabupaten 
Gorontalo. Berdasarkan jenis penelitiannya, penelitian ini tergolong sebagai penelitian survey explanatory yaitu survey yang digunakan untuk menghubungkan antara hipotesis penelitian. Alat pengumpulan data yang digunakan dalam penelitian ini mengacu pada instrument pokok berupa kuesioner. Alat ini digunakan untuk mengetahui hubungan antara gaya kepemimpinan dan kepribadian dengan etos kerja pegawai di Kantor Kecamatan Bongomeme Kabupaten Gorontalo.

Dengan mengacu pada pendapat Arikunto (2006: 8) bahwa bentuk penelitian deskriptif verifikatif yaitu penelitian yang menggambarkan tentang persepsi terhadap hubungan antara gaya kepemimpinan dan kepribadian dengan etos kerja di Kantor Kecamatan Bongomeme Kabupaten Gorontalo. Bentuk penelitian yang dilakukan ini akan diawali dengan observasi awal terhadap lokasi penelitian yakni di Kantor Kecamatan Bongomeme Kabupaten Gorontalo.

Dari jenis penelitiannya, metode penelitian yang digunakan dalam penelitian ini adalah explanatory survey. Menurut Sugiyono (2008:10) metode explanatory survey adalah metode penelitian yang dilakukan pada populasi besar atau kecil, dengan memfokuskan bentuk penelitian pada sampel penelitian yang telah ditentukan berdasarkan fenomena sosiologis dan psikologis yang ditemukan di lapangan. Metode ini juga diartikan sebagai bentuk penelitian yang menghubungkan antara variabel yang satu dengan variabel yang lainnya.

\section{HASIL PENELITIAN DAN PEMBAHASAN}

Hasil penelitian menunjukkan bahwa secara statistika terbukti variabel-variabel bebas yang diteliti ikut menentukan variabel terikat. Variabel-variabel yang dimaksud adalah variabel bebas terdiri dari Gaya Kepemimpinan Pimpinan dan Kepribadian Pimpinan, sedangkan variabel terikat adalah Etos Kerja Pegawai.

Pertama, hasil pengujian hipotesis pertama yang menyatakan bahwa: terdapat hubungan antara gaya kepemimpinan pimpinan dengan etos kerja pegawai. Hal ini ditunjukkan dengan oleh persamaan $\ddot{Y}=35,09+0,31 \mathrm{X}_{1}$ yang telah teruji keberartiannya pada $\mathrm{a}=0.05$. Selanjutnya melalui hasil pengujian koefisien korelasi sederhana diperoleh koefisien determinasi $r_{y 1}$ sebesar 0.02 ; koefisien determinasi $r_{x y}^{2}$ sebesar 0.004. Hal ini berarti etos kerja pegawai ditentukan oleh gaya kepemimpinan pimpinan.

Memperhatikan rata-rata hitung, modus dan median di atas nampak bahwa sebaran data cenderung memusat, karena modus, rata-rata, dan medan relatif memiliki harga yang sama dengan kisaran rata-rata skor 31. Hal ini memberikan gambaran bahwa untuk bentuk kurva normalnya simetrik. Kecenderungan data gaya kepemimpinan $\left(\mathrm{X}^{1}\right)$ divisualisasikan melalui gambar diagram berikut ini: 


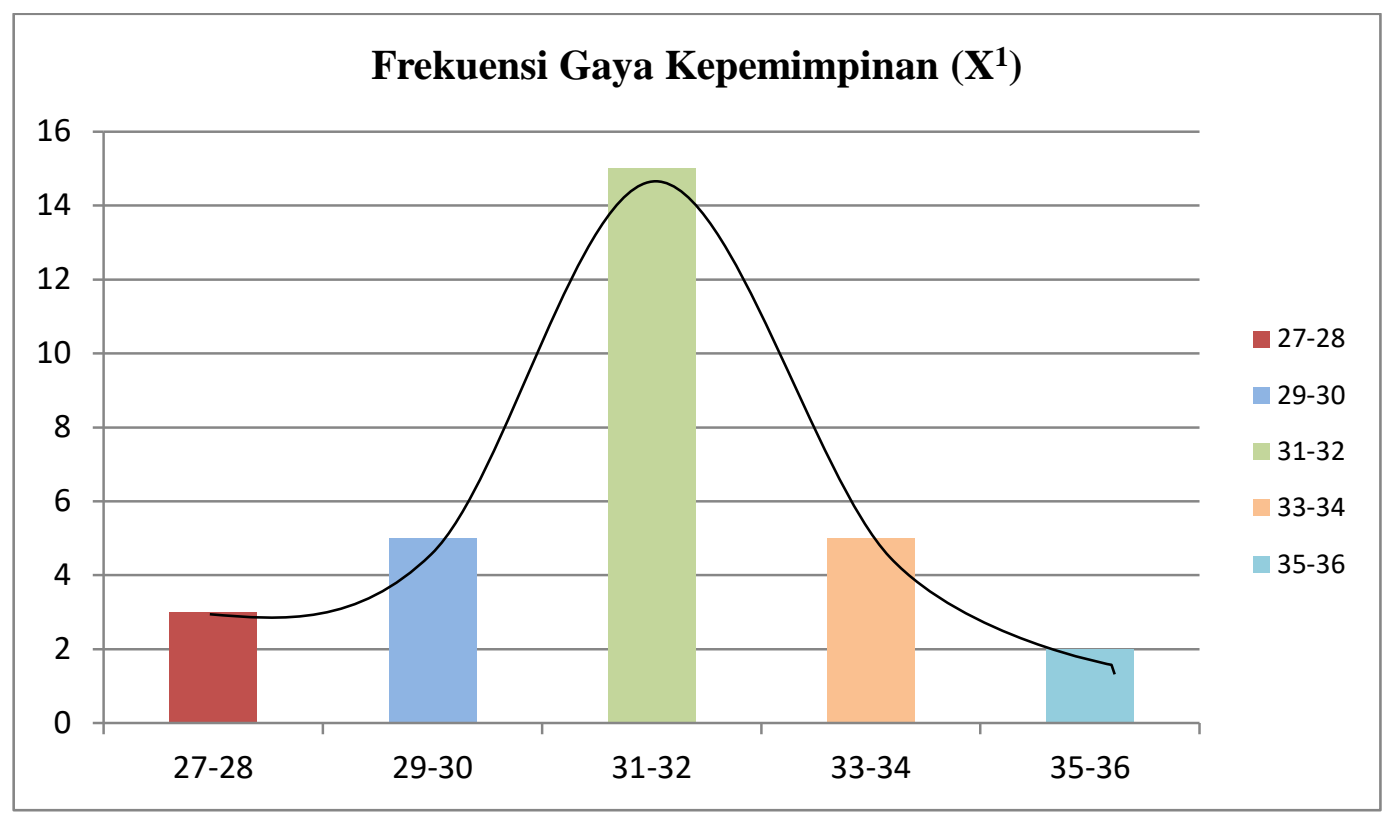

Gambar 4.1: Diagram Frekuensi Skor Gaya Kepimpinan

Kedua, hasil pengujian hipotesis kedua yang menyatakan bahwa terdapat hubungan antara kepribadian pimpinan dalam menjabat sebagai camat Bongomeme dengan etos kerja pegawai. Hal ini ditunjukkan oleh regresi linear persamaan sederhana $\ddot{Y}=13214,74+0,002 X_{2}$ yang telah teruji keberartiannya pada $\mathrm{a}=0.05$. Selanjutnya melalui hasil pengujian koefisien korelasi sederhana diperoleh koefisien determinasi $\mathrm{r}_{\mathrm{y} 1}$ sebesar 0,99; koefisien determinasi $\mathrm{r}_{\text {xy }}^{2}$ sebesar 1 . Hal ini berarti etos kerja pegawai ditentukan oleh kepribadian pimpinan.

Dengan meninjau besaran skor yang diperoleh dari median, modus, dan mean atau rata-rata hitung, jumlah skor yang diperoleh pada data kepribadian pimpinan $\left(\mathrm{X}^{2}\right)$ berada pada kisaran rata-rata skor 68. Hal ini memberikan gambaran bahwa untuk bentuk kurva normalnya simetrik. Untuk lebih jelasnya, kecenderungan data kepribadian divisualisasikan melalui gambar diagram berikut ini: 


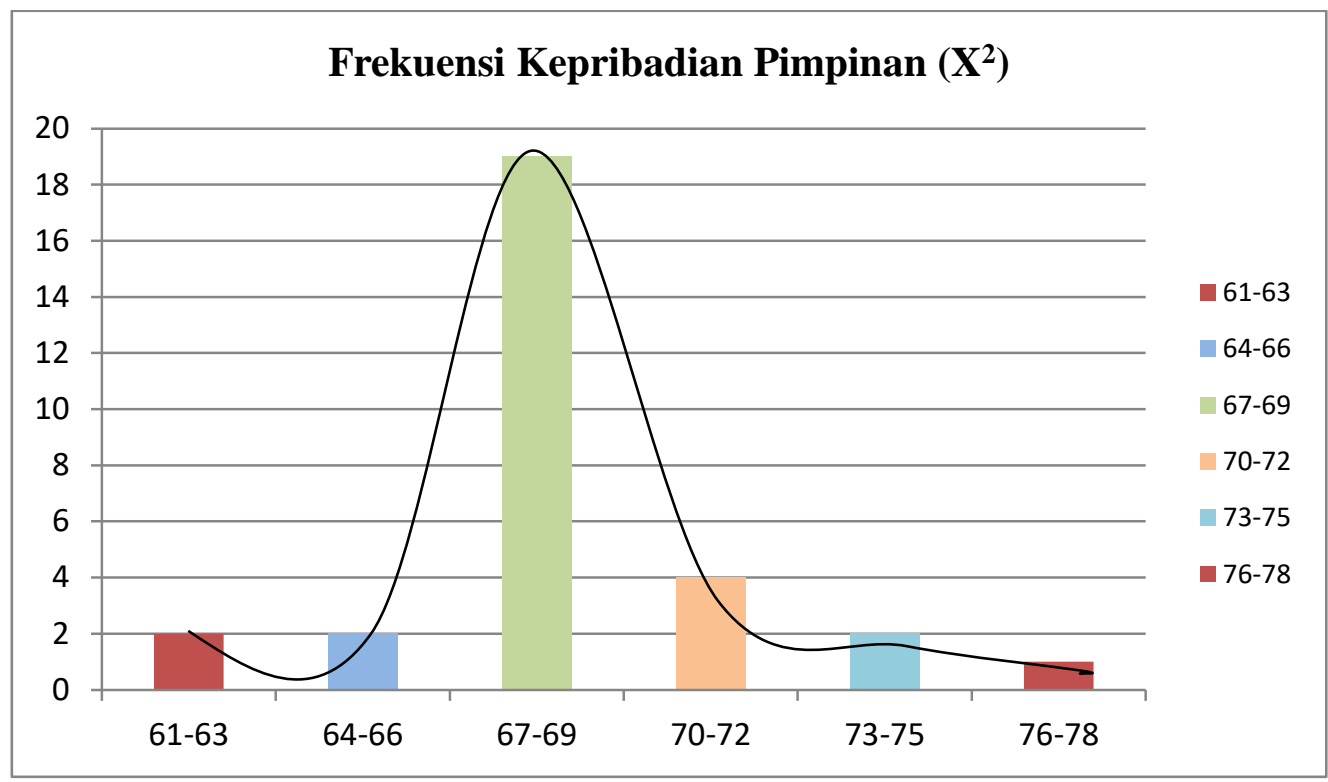

Gambar 4.2: Diagram Frekuensi Skor Kepribadian Pimpinan

Ketiga, dari hasil pengujian ketiga menunjukkan bahwa terdapat hubungan antara gaya kepemimpinan dan kepribadian pimpinan terhadap etos kerja pegawai di lingkungan kecamatan Bongomeme, Kabupaten Gorontalo. Hal ini ditunjukkan oleh regresi linear persamaan sederhana $\ddot{Y}=0,3-0,34 X_{1}+0,52 X_{2}$ yang telah teruji keberartiannya pada $\mathrm{a}=0.05 \mathrm{Hal}$ ini berarti etos kerja pegawai ditentukan oleh kedua variabel yaitu gaya kepemimpinan pimpinan dan kepribadian pimpinan.

Memperhatikan rata-rata hitung, modus dan median di atas nampak bahwa sebaran data cenderung memusat, karena modus, rata-rata, dan medan relatif memiliki harga yang sama. Hal ini memberikan gambaran bahwa untuk bentuk kurva normalnya simetrik. Kecenderungan data responden pada distribusi frekuensi etos kerja pegawai dapat divisualisasikan melalui gambar diagram berikut ini:

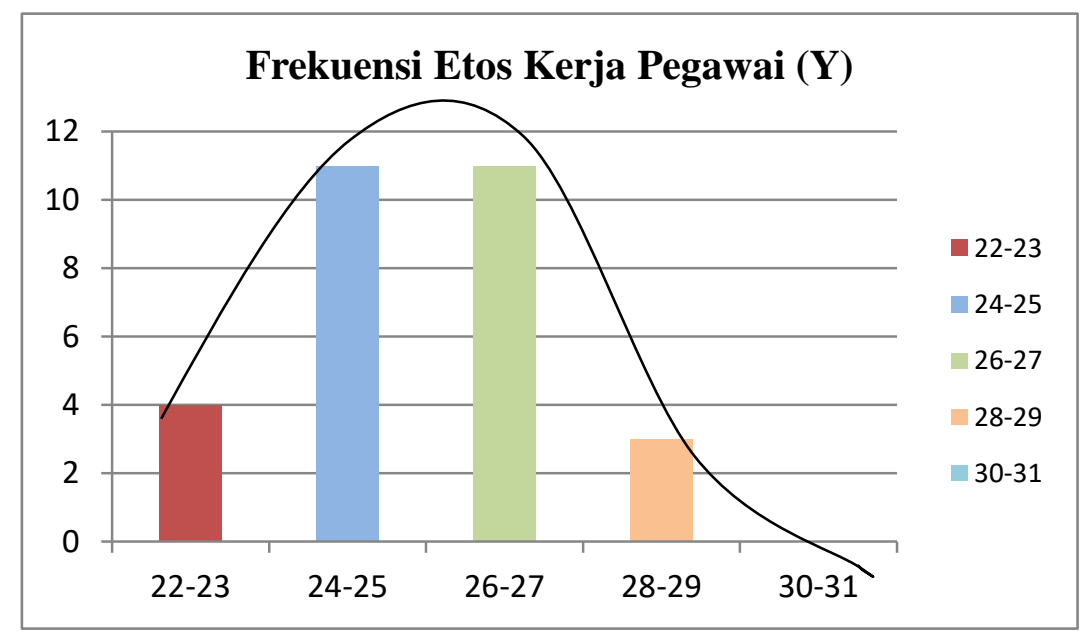

Gambar 4.4: Diagram Frekuensi Etos Kerja Pegawai 
Terkait dengan keterkaitan antara gaya kepemimpinan dan kepribadian pimpinan terhadap etos kerja pegawai, ada beberapa temuan dari hasil wawancara yang dapat mendukung hubungan ketiga variabel dalam menterjemahkan setiap kegiatan yang terjadi di lingkungan kecamatan Bongomeme, Kabupaten Gorontalo, khususnya terkait dengan ketiga aspek tersebut. Satu hal yang ditemukan dalam penelitian ini adalah strategi yang dilakukan camat yaitu kunjungan langsung setiap sub bagian atau setiap seksi untuk mengetahui proses perkembangan atau tugas mereka. Dari hasil wawancara dengan Camat Bongomeme: "saya melakukan pengawasan dengan melakukan kunjungan, dari kunjungan tersebut maka saya dapat mengetahui perkembangan tugas pegawai sehingga dapat memberikan masukan yang sifatnya objektif".

Temuan lainnya bahwa camat melakukan evaluasi biasanya melakukan inspeksi yang mendadak untuk mengetahui proses perkembangan kinerja setiap pegawai. Hasil wawancara dengan pegawai berinisial $N R$ : "biasanya beliau langsung melakukan kunjungan langsung setiap sub bagian atau setiap seksi untuk memantau langsung kinerja pegawai”.

Hasil penelitian lainnya jelas menunjukkan bahwa camat melakukan kegiatan tindak lanjut untuk memperbaiki kinerja pegawai. Kegiatan tindak lanjut dalam evaluasi kinerja pegawai dilakukan camat dengan cara memberikan penghargaan terhadap pegawai yang berkinerja baik dan pembinaan terhadap pegawai yang berkinerja kurang baik. Hal ini menjadikan pegawai semakin bersemangat untuk memperbaiki kinerja para pegawai yang ada di Kantor Camat Bongomeme.

Temuan penelitian di atas menunjukkan bahwa camat telah menunjukkan peran yang baik dalam pengawasan kinerja pegawai. Kemampuan camat dalam menunjukkan peran pengawasan yang baik tersebut perlu terus ditingkatkan dengan cara melakukan pengawasan dan pembinaan kepada pegawai untuk tidak merasa di awasi dalam bekerja, serta berupaya bekerja dengan baik meskipun tanpa diawasi oleh pimpinan.

Berdasarkan temuan penelitian tersebut, kesimpulan dalam penelitian ini adalah etos kerja pegawai memiliki keterkaitan dengan gaya kepemimpinan dan kepribadian pimpinan. Apa yang dilakukan oleh pimpinan akan menentukan etos kerja pegawai di lingkungan instansi terkait, khususnya pada lingkungan kecamatan Bongomeme Kabupaten Gorontalo. Dalam hal ini, untuk meningkatkan etos kerja pegawai, pola tingkah laku pimpinan dapat ditunjukkan melalui evaluasi berkesinambungan yang dilakukan pimpinan dengan bersikap terbuka dan supel terhadap pegawai sehingga etos kerja dapat meningkat dengan baik

\section{KESIMPULAN}

1) Hubungan yang signifikan antara gaya kepemimpinan pimpinan $\left(X_{1}\right)$ dengan etos kerja pegawai (Y), yang ditunjukkan koefisien korelasi sederhana diperoleh koefisien $r_{\mathrm{y} 1}$ sebesar 0,02 dan koefisien determinasi $r_{y 1}^{2}$ sebesar 0,004. Hal ini mengindikasikan bahwa makin tinggi gaya kepemimpinan yang ditunjukkan oleh pemimpin, maka akan semakin tinggi etos kerja pegawai.

2) Hasil pengujian kedua menyimpulkan bahwa terdapat hubungan yang signifikan antara kepribadian pimpinan $\left(\mathrm{X}_{2}\right)$ dengan etos kerja pegawai $(\mathrm{Y})$, yang ditunjukkan koefisien korelasi sederhana diperoleh koefisien $\mathrm{r}_{\mathrm{y} 1}$ sebesar 0,99 dan koefisien determinasi $\mathrm{r}_{\mathrm{y} 1}^{2}$ sebesar 1 . Hal ini mengindikasikan bahwa makin tinggi nilai 
kepribadian pemimpin yang ditunjukkan dalam kinerjanya, maka akan semakin tinggi etos kerja pegawai.

3) Hasil pengujian ketiga menyimpulkan bahwa terdapat hubungan yang signifikan antara gaya kepemimpinan (X1) dan kepribadian pimpinan $\left(\mathrm{X}_{2}\right)$ dengan etos kerja pegawai (Y), yang ditunjukkan koefisien korelasi multiple regresi. Hal ini mengindikasikan bahwa makin tinggi nilai gaya kepemimpinan dan kepribadian pemimpin yang ditunjukkan dalam kinerjanya, maka akan semakin tinggi etos kerja pegawai.

\section{DAFTAR RUJUKAN}

Aditya, Regina. 2010. Pengaruh Gaya Kepemimpinan, Motivasi dan Disiplin Kerja terhadap Kinerja Karyawan PT Sinar Sentosa Perkasa Banjarnegara.

Arikunto, S. 2001. Dasar-Dasar Evaluasi Pendidikan.Jakarta: Bumi Aksara

Cichoki, P \& Irwin, C. 2011.Organization Design: A Guide to Building Effective Organization. New Delhi: Kogan Page Limited

Djaali, 2000.Pengukuran dalam Bidang Pendidikan.Jakarta: Program Pascasarjana Universitas Negeri Jakarta

Nasution, Nur. 2012. Manajemen Mutu Terpadu. Bogor: Ghalia Indonesia.

Puspitasari, M dan Nina Oktarina. 2018. 'Pengaruh Gaya Kepemimpinan, Budaya Organisasi, dan Tata Ruang Kantor terhadap Kinerja Pegawai'. Jurnal Scopus Internasional.Economic Education Analysis Journal 7 (1) (2018).dalam situs http://journal.unnes.ac.id/sju/index.php/eeaj

Sugiyono. 2011. Metode Penelitian Survey. Bandung: Alfabet

Wahyuni, Sri. 2009. Pengaruh Kepemimpinan terhadap Prestasi Kerja Karyawan LAZIS (UII) Universitas Islam Indonesia Yogyakarta

Widiyanti, A, D.Lie, M. Butarbutar, dan A. Wijaya, 2018."Pengaruh Gaya Kepemimpinan dan Budaya Organisasi terhadap Kinerja Karyawan pada PT Bank Sumut Kantor Cabang Syariah Pematang siantar. Google Scholar. Sulltanist 6 (2), 2018.

Wijayanti, AA, I. Isharijadi, dan J. Murwani. 2017. “Analisis Human Relation dan Kondisi Fisik Lingkungan dalam Mengembangkan Etos Kerja Karyawan PT KAI DAOP VII Madiun. Google Scholar. FIPA. Forum Ilmiah Pendidikan Akuntansi 5 (1), 2017

Wood, J. M. et.al. 2001. Organizational Behavior: A Global Perspective $2^{\text {nd }}$ Edition. Australia: John Willey and Son Australia. Ltd

Yudha, D. AQ Djaelani. 2019. "Pengaruh Kompensasi, Gaya Kepemimpinan, dan Motivasi Kerja terhadap Kinerja Karyawan pada Koperasi Unit Desa Pakis Kabupaten Malang”. Google Scholar. Jurnal Ilmiah Riset Manajemen 8 (10), 2019.

Zakiyah, SN dan S. Sudarijati. 2017. "Pengaruh Kondisi Fisik Lingkungan Kerja dan Kepemimpinan terhadap Etos Kerja Pegawai pada Biro Hubungan Masyarakat Kementerian Lingkungan Hidup dan Kehutanan Jakarta". Googlle Scholar. Jurnal Visonida 3 (1), 13-19. 